\title{
PENGARUH STRUKTUR BAHASA ARAB TERHADAP BAHASA INDONESIA DALAM TERJEMAHAN AL-QUR'AN*
}

\author{
Yayan Nurbayan \\ Universitas Pendidikan Indonesia, Bandung \\ email : nurbayan_upi@yahoo.co.id
}

\begin{abstract}
The process of translation in fact gave birth to a sociolinguistic phenomenon like bilingualism when the structure of a language that translated influence on the translation. This paper examines the translation of the Koran, which follows the pattern of the structure of the Arabic language in terms of word order (sequence pattern) element of Arabic and Indonesian. Based on the analysis of the function, the result of translation is not necessarily a literal translation has the same syntactic pattern with the source text. Indonesian function often different in sentence patterns with sentence patterns of Arabic, although it is the literal translation of the Arabic sentence. It happened because of the workings of the Arabic grammarians differ from Indonesian linguist in analyzing its function.
\end{abstract}

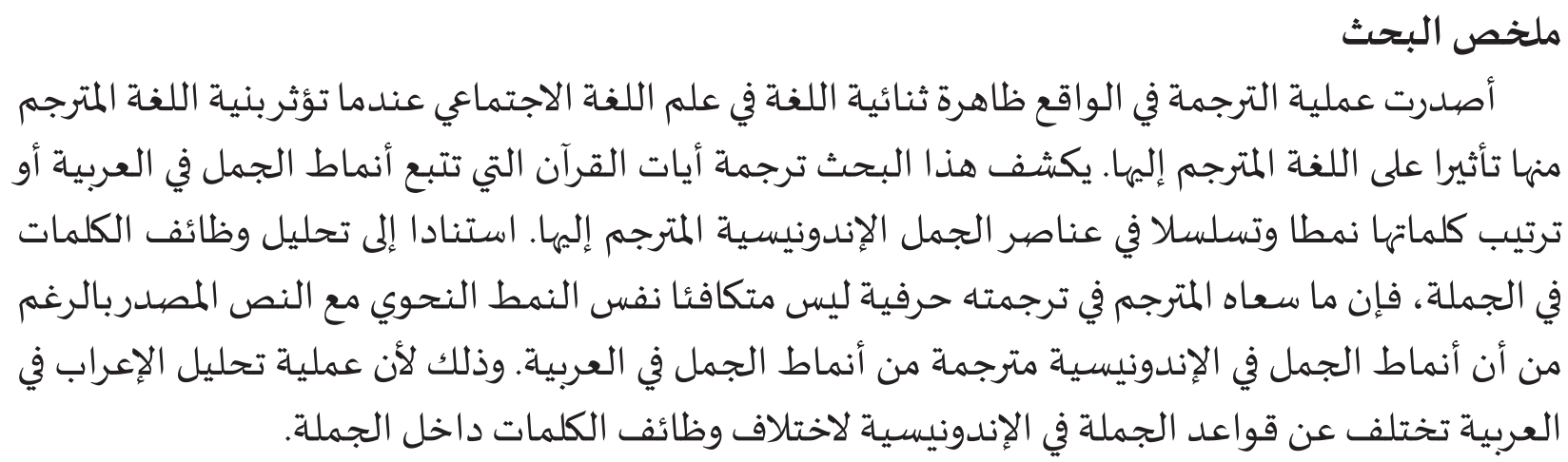

Kata Kunci: , terjemah al-Qur'an, bahasa Arab, bahasa Indonesia, pengaruh, struktur kalimat

\section{Pendahuluan}

Kegiatan penerjemahan mempunyai peranan penting dalam mentrasfer ilmu pengetahuan dan informasi dalam berbagai bidang kehidupan seperti bidang agama, sosial-politik, ekonomi, dan budaya. Kegiatan tersebut memberikan andil yang cukup besar dalam alih teknologi, penyebaran informasi, dan peningkatan sumber daya manusia.

Dengan semakin terbukanya komunikasi antarperadaban, penerjemahan antar bahasa semakin menempati posisi penting. Kebutuhan manusia akan informasi, pengetahuan, dan teknologi dari pihak lain semakin terasa dan semakin meningkat. Menurut Majid, peradaban Islam pertama-tama berkembang melalui penerjemahan karya-karya lama Yunani, Persia, India, dan Mesir dalam bidang ilmu eksakta dan kedokteran. Kegiatan ini dimulai pada masa pemerintahan Khalifah Abu Ja'far al-Manshur (137-159H/ 754775M.), salah seorang khalifah dari Dinasti Abbasiah. Upaya itu mencapai kegairahan yang menakjubkan pada masa Khalifah 
al-Makmun sehingga mengantarkan umat Islam ke masa keemasan. ${ }^{1}$

Di Indonesia, kebutuhan pada hasilhasil penerjemahan, khususnya buku-buku keagamaan sangat tinggi. Hal ini dapat kita lihat dari menjamurnya penerbit buku keagamaan yang menerbitkan karya terjemahan. Namun, kualitas penerjemahan dari bahasa Arab ke dalam bahasa Indonesia masih menemui beberapa kendala. Menurut Syihabuddin, ada empat kendala dalam penerjemahan teks Arab ke dalam bahasa Indonesia, yaitu: 1) kesulitan dan kerumitan dalam kegiatan penerjemahan; 2) perbedaan subtsansial antara bahasa Arab dan bahasa Indonesia; 3) kelemahan penguasaan penerjemah terhadap bahasa penerima sehingga menimbulkan gejala interferensi, dan 4) kelemahan penguasaan penerjemah terhadap teori terjemah. ${ }^{2}$

Proses penerjemahan melibatkan berbagai aspek akademik yang perlu dipenuhi agarsebuahterjemahanmencapaifungsinya. Aspek tersebut di antaranya: metode penerjemahan, penguasaan dua bahasa atau lebih oleh penerjemah, penguasaan disiplin ilmu yang diterjemahkan, dan hal-hal terkait lainnya dalam praktik penerjemahan. Salah satunya adalah pergeseran (distorsi) makna yang disebabkan oleh perbedaan muatan semantis suatu ungkapan, perbedaan bentuk/pola kata, perbedaan struktur kalimat, perbedaan budaya ungkap, dan perbedaan konteks kalimat.

Ihwal pergeseran makna akibat perbedaan konteks kalimat, Muhammad Enani (Universitas Kairo) mengkritik hasil terjemah al-Qur'an yang dilakukan oleh A.J. Arberry yang menerjemahkan semua kata

1 Majid, A.M., Sejarah Kebudayaan Islam, terjemah Ahmad Rafi Usmani (Bandung: Pustaka, 1997), h. 98-99.

2 Syihabuddin, Penerjemahan Arab Indonesia: Teori dan Praktek (Bandung: Humaniora, 2005), h. 3. rahmah dengan mercy. Kata mercy, menurut Enani, tidak bisa mencakup semua makna rahmah dalam konteks yang beragam. Enani juga mengingatkan bahwa penerjemah yang benar-jujur (shâdiq) semestinya tidak menyamakan terjemah suatu kata dengan padanan tertentu. Sebaliknya, ia harus memperhatikan konteks kalimat (siyâq alkalâm). ${ }^{3}$

Selanjutnya, penguasaan penerjemah atas dua bahasa atau lebih secara praktis telah melahirkan gejala sosiolinguistik yang dikenal dengan kedwibahasaan. Gejala ini timbul karena kontak antar dua bahasa yang dikuasai oleh penerjemah. Dalam kasus penerjemahan al-Qur'an, wujud kedwibahasaannya adalah pemakaian bahasa Arab dan bahasa Indonesia.

Pemakaian bahasa Arab dan bahasa Indonesia secara teoretis dapat menimbulkan gejala saling mempengaruhi antara bahasa Arab dan bahasa Indonesia yang ditandai oleh pemakaian unsurunsur bahasa Arab dalam terjemahan al-Qur'an. Hal ini diasumsikan dapat mengganggu keterpahaman terjemahan dan menyulitkan pembaca dalam menyimpulkan makna. Kesulitan ini pada akhirnya dapat menimbulkan kesalahan dalam menyimpulkan maksud ayat. Hal inilah yang mendorong peneliti untuk mengkaji masalah tersebut lebih mendalam lagi.

Dalam penelitian ini, akan dikaji pengaruh struktur bahasa Arab ke dalam bahasa Indonesia pada terjemahan alQur'an yang diterbitkan oleh Departemen Agama (kini Kementerian Agama) Republik Indonesia. Pemilihan terjemah al-Qur'an terbitan Departemen Agama RI didasarkan

3 Muhammad Enani, Fann al-Tarjamah (Beirut: Maktabah Lubnan Nasyirun, 2004), cet. ke-7, h.16-17. 
pada beberapa asumsi berikut:

1) terjemahan tersebut merupakan hasil karya sekelompok ahli agama Islam, ahli tafsir, dan ahli bahasa Arab yang sudah diakui kepakarannya di tingkat nasional bahkan internasional;

2) terjemahan itu dibaca dan dijadikan rujukan oleh ratusan juta umat Islam dari berbagai kalangan;

3) terjemahan itu diterbitkan oleh Departemen Agama dan beberapa penerbit lain, baik di dalam maupun di luar negeri;

4) penerjemahan dikerjakan selama delapan tahun. Dari kualifikasi yang ada, produk terjemahan al-Qur'an Departemen Agama RI tersebut secara teoretis berkualitas. ${ }^{4}$

\section{Rumusan Masalah}

Masalah pokok penelitian ini berkaitan dengan pengaruh struktur Bahasa Arab (BA) dalam terjemahan Bahasa Indonesia (BI). Untuk memecahkan masalah tersebut, setidaknya kita harus menjawab rumusan masalah berikut:

1) Adakah penerjemahan yang mengikuti pola struktur BA dan adakah yang tidak mengikutinya?;

2) Adakah jenis terjemahan yang gramatis atau yang tidakgramatis menurutkaidah BI di antara kedua hasil penerjemahan tersebut?;

3) Adakah pengaruh BA ke dalam BI?

\section{Landasan Teoretis}

Muhammad 'Abd al-'Azhim al-Zarqani mendefinisikan terjemah (tarjamah) sebagai pengungkapan makna pembicaraan dari suatu bahasa dengan pembicaraan

\footnotetext{
4 Syihabuddin, loc. cit, h. 3.
}

lain dari bahasa yang berbeda dengan memenuhi semua makna dan maksudnya. ${ }^{5}$ Manna' Khalil al-Qaththan mengungkapkan: "Terjemah adalah menjelaskan pembicaraan asli atau memperhatikan susunannya". 6

Menurut Moeliono, pada hakikatnya penerjemahan merupakan kegiatan memproduksi amanat atau pesan bahasa sumber dengan padanan yang paling dekat dan wajar di dalam bahasa penerima, baik dilihat dari segi arti maupun dari segi gaya. Idealnya terjemahan tidak akan dirasakan sebagai terjemahan. ${ }^{7}$

Pada bagian lain, Catford mengatakan, "Translation is replacement of textual material in one language (SL) by equivalent textual material ini another (TL)". 8 Nida dan Taber mengatakan: "Penerjemahan adalah usaha mencipta kembali pesan dalam Bahasa Sumber (BS) ke dalam Bahasa Target (BT) dengan padanan alami yang sedekat mungkin, pertama dalam hal maknanya, lalu gaya bahasanya (translation consists of reproducing in the receptor language the closed natural equivalent of the sources language message, first in terms of meaning and secondly in terms of style)". ${ }^{9}$ Definisi ini menekankan pada kesepadanan pesan antara teks yang diterjemahkan dan hasil terjemahan dengan mengungkapkan maknanya dan gaya bahasanya. ${ }^{10}$

5 Muhammad 'Abd al-'Azhim al-Zarqani, Manâhil al-'Irfân fî 'Ulûm al-Qur'ân (Mesir: Mustafa al-Bab al-Halabi wa Auladuh, 1411), h. 666.

6 Manna' Khalil al-Qaththan, Mabâhits fì 'Ulûm al-Qur'ân (Kairo: Maktabah Wahbah, 2000), h. 307.

7 A.M. Moeliono (ed), Tata Bahasa Baku Bahasa Indonesia (Jakarta: Balai Pustaka, 1989), h. 195.

$8 \quad$ C.J. Catford, A Linguistic Theory of Translation (Oxford: Oxford University Press, 1965), h. 20.

9 Eugene A. Nida dan Charles R. Taber, The Theory and Practice of Translation (Leiden: E.J. Brill, 1982), h. 12. Lihat juga Rochayah Machali, Redefining Textual Equivalence in Translation (Jakarta: Pusat Penerjemahan Fakultas Sastra UI, 1998), h. 1.

10 Harimurti Kridalaksana, Fungsi Bahasa dan Sikap Bahasa (Ende: Nusa Indah, 1999), cet. XI, h. 77. 
Adapun Wolfram Wilss dalam The Science of Translation mengatakan, "Penerjemahan adalah suatu proses transfer yang bertujuan untuk mentransformasikan teks tertulis dalam Bahasa Sumber (BS) ke dalam teks Bahasa Target (BT) yang optimal padan, dan memerlukan pemahaman sintaksis, semantik, dan pragmatik, serta proses analisis terhadap BS."11

Definisi-definisi di atas, dapat disimpulkan berikut ini:

1) Penerjemahan bertujuan memindahkan pesan bahasa sumber (BS) kepada bahasa target (BT) dengan cara menemukan padanan bentuk-bentuk dari BS di dalam BT.

2) Penerjemahan berkaitan dengan teks yang diterjemahkan, dan penggantian teks BS dengan teks BT harus akuivalen (sama dan sepadan). Hal ini menyiratkan bahwa terjemahan biasanya dilakukan bukan dalam tataran kalimat, melainkan dalan tataran wacana.

Sebagaimana para ahli mempunyai titik pandang yang berbeda tentang istilah terjemah, mereka juga memiliki titik pandang dan peristilahan berbeda-beda tentang macam-macam terjemah. Zarqani membagi terjemah menjadi dua jenis sebagai berikut: ${ }^{12}$

1. Terjemahan harfiyyah, yaitu terjemahan yang memperhatikan kesamaannya dengan yang asli dalam hal susunan dan urutannya. Terjemahan demikian serupa dengan penetapan persamaan kata atau padanannya dari bahasa asli.

11 Wolfram Wilss, The Science of Translation (Stuttgart: Gunter Narr Verlag Tubingen, 1982), h. 3. Lihat juga: Zuchridin Suryawinata dan Sugeng Hariyanto, Translation: Bahasan Teori dan Penuntun Praktis Menerjemahkan (Yogyakarta: Kanisius, 2003), cet. I, h. 15-16.

12 Muhammad 'Abd al-'Azhîm al-Zarqânî, op. cit., h. 677.
2. Terjemah tafsîriyyah, yaitu terjemahan yang tidak memperhatikan kesamaannya dengan yang asli dalam hal susunan dan urutannya, tetapi yang terpenting adalah penggambaran makna dan tujuan dengan baik dan sempurna.

Menurut Mansyur dan Kustiwan dalam kaitannya dengan terjemah al-Qur'an, untuk beberapa ayat tertentu terjemah harfiah dilarang, terutama apabila berakibat pada perubahan makna dari yang seharusnya. Terjemah tafsîriyyah lebih tepat, karena pada hakikatnya terjemah adalah memindahkan makna dari bahasa asal ke bahasa tujuan. Artinya, yang mesti utuh dan tidak boleh berubah adalah makna. ${ }^{13}$

Sementara Catford membagi terjemah ke dalam dua jenis:

1. Total translation. Total translation may be best defined as replacement of $S L$ grammar and lexis equivalent TL grammar and lexis with consequential replacement ofSL phonology/graphology by (non-equivalent) TL phonology/ graphology.

2. Restriced translation. By restricted translation we mean replacement of $S L$ textual material by equivalent $T L$ textual material, at only one level, that is translation performed only at phonological or at the graphonological level, or at only one of the two levels of grammar and lexis. ${ }^{14}$

Pembagian dua ahli di atas, dapat disimpulkan bahwa terjemahan dapat ditinjau :

1. Menurut cara menerjemahkan, yaitu terjemah harfiah dan maknawiah atau total translation dan restriced translation.

13 Mansyur dan Kustiwan, Dalîl al-Kâtib wa alMutarjim (Jakarta: Moyo Segoro Agung, 2002), h. 53.

14 J.C. Catford, A Linguistic Theory of Translation (Oxford: Oxford University Press, 1965), h. 20. 
2. Menurut cara menyampaikan hasil terjemahan, yaitu lisan dan tulisan.

\section{Metode Penelitian}

Metode yang digunakan dalam penelitian ini adalah metode deskriptif analitis. Penelitian ini mencoba membandingkan ayat al-Qur'an dan terjemahannya dengan menggunakan analisis komparatif. Oleh karena itu, metode yang digunakan dalam penelitian ini dapat juga disebut metode deskriptif-komparatif.

Ada dua teknik yang digunakan dalam penelitian ini, yakni teknik dokumentasi dan teknik analisis. Sumber data penelitian ini adalah dokumen yang berupa mushaf al-Qur'an dan terjemahannya. Data yang terdapat dalam dokumen mushaf al-Qur'an dan terjemahannya ini dianalisis dengan dua langkah analisis, yaitu: (1) langkah penelusuran dan (2) analisis terjemahan (BI) yang dipengaruhi pola susunan BA.

Langkah penelusuran berupa analisis komparatif terhadap pola-pola sintaksis ayat al-Qur'an dan pola-pola sintaksis terjemahannya. Ayat al-Qur'an yang dijadikan sampel adalah Suratal-Baqarah yang terdiri atas 286 ayat. Surah ini ditelusuri seluruhnya dengan cara membandingkan ayat tersebut dengan terjemahannya. Terjemahan yang terbukti mengandung pengaruh dari BA dianalisis dan dibahas lebih lanjut pada langkah analisis berikutnya.

\section{Hasil dan Pembahasan}

Sebagaimana dijelaskan di muka bahwa masalah pokok dalam penelitian ini berkaitan dengan pengaruh struktur bahasa Arab (BA) dalam terjemahan berbahasa Indonesia (BI). Untuk memecahkan masalah tersebut, setidaknya kita harus menjawab rumusan masalah: Adakah penerjemahan yang mengikuti pola struktur BA dan adakah yang tidak? Adakah di antara kedua jenis terjemahan itu yang gramatis atau yang tidak menurut kaidah BI? Adakah pengaruh struktur BA ke dalam struktur BI?

Penerjemahan tidak lepas dari bagian struktur sintaksis bahasa sumber dan struktur sintaksis bahasa sasaran. Pola struktur sintaksis BA banyak yang sama dengan pola struktur sintaksis BI seperti hukum DM, kalimat nominal, kalimat verbal, dan lain-lain. Di samping banyak kesamaan ada pula perbedaannya. Misalnya bahasa Arab sering menggunakan pola PS, PSO, POS, OSP, S Ket PO, dan SP Ket O, yang dalam pola struktur BI jarang sekali terjadi.

Berdasarkan penelitian yang dilakukan, dapat dilihat hasil-hasil sebagai berikut :

1. Baik BA maupun BI ternyata menggunakan hukum diterangkan menerangkan (DM). Dengan demikian, terjemahan harfiah dari BA ke BI sering melahirkan pola struktur BI yang gramatis.

2. Berdasarkan hasil penelitian, ditemukan berbagai cara penerjemahan ditinjau dari segi "sama atau tidaknya" susunan kata dalam BA dan BI. Berdasarkan hal itu ditemukan klasifikasi terjemahan sebagai berikut:

a. Penerjemahan yang mengikuti pola struktur BA dan melahirkan terjemahan yang gramatis;

b. Penerjemahan yang mengikuti pola struktur BA dan melahirkan terjemahan yang tidak gramatis;

c. Penerjemahan yang tidak mengikuti pola struktur BA dan melahirkan terjemahan yang gramatis;

d. Penerjemahan yang tidak mengikuti pola struktur BA dan melahirkan terjemahan yang tidak gramatis.

3. Mencermati 286 ayat surah al-Baqarah terdapat 19 ayat yang mengandung 
terjemahan yang mendapat pengaruh dari BA dan menghasilkan terjemahan dengan struktur BI yang kurang lazim. Berdasarkan analisis terhadap data yang berupa terjemahan yang berkarakteristik demikian, ditemukan berbagai tipe pengaruh BA ke dalam BI. Berbagai tipe itu akan dipaparkan sebagai berikut:

a. Terjemahan harfiah yang mengikuti pola BA sering menghasilkan pola BI yang kurang lazim. Ketidaklaziman itu di antaranya karena penerjemahan kata depan (huruf Jar): min, 'an, 'ala, dan sebagainya secara tidak tepat. Misalnya, "'alaihim" diterjemahkan atas mereka atau terhadap mereka dalam konteks "niscaya tidak ada kekhawatiran atas mereka." Pada ayat lain, diterjemahkan terhadap mereka yang merupakan terjemahan harfiah dari "lâ khaufun 'alaihim." Kata "atas" dan "terhadap" sebaiknya diganti dengan kata pada sehingga terjemahannya menjadi Orang yang mengikuti petunjuk-Ku tidak ada ke-khawatiran pada diri mereka.

b. Dalam al-Qur'an kata kerja seperti kata kerja seperti ta'lamûn, ta'qilûn banyak sekali kita temukan di ujung ayat. Terjemahan ayat-ayat seperti ini di dalam BI tergolong kata kerja transitif. Apabila kata kerja transitif tersebut terletak di ujung kalimat, maka melahirkan struktur yang tidak lazim. Misalnya, "wa antum ta'lamûn" (sedangkan kamu mengetahui). Jelaslah di sini bahwa bentuk "sedang kamu mengetahui" merupakan klausa yang merupakan pengaruh dari BA. Kalau kita kaji, penghilangan objek tersebut tidak menimbulkan perubahan makna, bahkan tampak sangat efisien. Dengan demikian, pengaruh BA yang semacam ini tergolong pengaruh yang positif.

c. Terjemahan itu Di antaranya ada yang mengubah pola aktif dalam BA menjadi pola pasif dalam BI. Dalam terjemahan al-Qur'an ditemukan bahwa pola aktif BA berpadanan dengan pola pasif BI. Sebagai contoh, kita ambil terjemahan penggalan ayat 59: "Sebab itu kami timpakan atas orang-orang yang zalim itu siksa dari langit". Cara yang demikian sangat efektif. Sebab, apabila kata kerjanya dibiarkan dalam bentuk aktif menimpakan, maka akan melahirkan pola kalimat SP Ket O yang dalam BI tidak diterima.

d. Kata kerja aktif dalam BA diterjemahkan dengan kata kerja pasif yang mengandung persona. Berbeda dengan kasus penerjemahan QS al-Baqarah (2): 59 (.... Sebab itu Kami timpakan pada orang-orang yang lalim itu siksa dari langit karena mereka berbuat fasik), pada penerjemahan penggalan ayat 66 ini, pengubahan aktif ke pasif tidak tepat karena kata kerja aktifnya memiliki dua objek. Apabila dipasifkan, maka salah satunya, yaitu 0 1, menjadi subjek. Dengan demikian, apabila urutan katanya dipertahankan seperti urutan BAnya, maka pola terjemahan tersebut menjadi PSO (S terselip di antara P dan 0): Maka Kami jadikan yang demikian itu peringatan.

e. Klausa Dia mengeluarkan bagi kami dari apa yang ditumbuhkan bumi, yaitu sayur-sayuran, ketimunnya, bawang putihnya, kacang adasnya, 
dan bawang merahnya... (QS alBaqarah [2]: 61) merupakan aktif dengan predikat (P) berupa kata kerja aktif transitif. Objek (O) harus berupa nomina atau frase nomina; sedangkan dalam terjemahan tersebut 0 berupa frase depan. Karena itu, kata dari yang terletak di depan 0 tersebut harus dihilangkan. Munculnya kata dari pada terjemahan tersebut akibat terjemahan harfiah kata min dalam mimma. Pola terjemahan tersebut merupakan pengaruh dari BA.

f. Terdapat ketidaklaziman struktur BI dalam terjemahan karena susunan katanya. Misalnya, kita temukan pada terjemahan ayat berikut: Dan tiada bagimu selain Allah seorang pelindung maupun seorang penolong (QS al-Baqarah [2]:107).Kata"tiada" pada terjemahan penggalan ayat 107 ini sebenarnya menegatifkan pelindung dan penolong, bukan menegatifkan bagimu. Oleh karena itu, sebaiknya kata "tiada" itu diletakkan langsung di depan yang dinegatifkannya. Sebaliknya diperbaiki seperti berikut : "Dan tiada pelindung maupun penolong bagimu selain Allah atau Dan bagimu tiada pelindung maupun penolong selain Allah."

g. Banyaksekaliditemukanterjemahan yang berpola SP Ket O. Misalnya, kita temukan pada terjemahan berikut:... kamu mendatangkan kepada orangorang Yahudidan Nasraniyang diberi al-Kitab (Taurat dan Injil), semua ayat (keterangan),.... Terjemahan penggalan QS al-Baqarah (2): 145 ini berpola S P Ket O. Terjemahan tersebut dapat diperbaiki menjadi: ... kamu mendatangkan semua ayat (keterangan) kepada orang-orang (Yahudi dan Nasrani) yang diberi al-Kitab (Taurat dan Injil).... Contoh lain kita temukan pada terjemahan berikut: ...dan Allah menurunkan bersama mereka kitab yang benar (QS al-Baqarah [2]: 213). Pengaruh BA yang serupa kita jumpai pada penerjemahan penggalan QS alBaqarah (2) ayat 251: ... kemudian Allah memberikan kepadanya (daud) pemerintahan dan hikmah, ... dan pada penerjemahan ayat 258: ... Allah telah memberikan kepada orang itu pemerintahan (kekuasaan), juga pada penerjemahan ayat 266 : Dia mempunyai dalam kebun itu segala buah-buahan.

h. Terdapat ketidaklaziman struktur BI dalam terjemahan karena sulitnya mencari redaksi terjemahan yang tepat dan lazim menurut kaidah BI. Misalnya, kita lihat pada contoh berikut: Dan bagi tiap-tiap ummat ada kiblatnya (sendiri) yang ia menghadap kepadanya (QS alBaqarah [2]: 148). Apabila kalimat di atas hendak disesuaikan dengan kalimat BI, maka akan menjadi: Setiap umat mempunyai kiblat yang ia hadapi. Namun, terjemahan seperti itu juga tidak memuaskan. Untuk menerjemahkan ayat seperti itu kiranya perlu dilakukan penerjemahan yang bebas, yakni penerjemahan yang hanya menangkap maksud ayatnya. Misalnya, ayat di atas dapat diterjemahkan menjadi :

1) Bagi tiap-tiap ummat ada kiblatnya sendiri; atau

2) Tiap-tiap ummat memiliki kiblat sendiri 
4. Di samping temuan-temuan utama tersebut di atas, penelitian ini menemukan berbagai temuan sampingan di bidang fonologi dan ejaan, morfologi, sintaksis, dan semantis. Di bidang fonologi, ditemukan berbagai cara penulisan kata yang tidak sesuai dengan EYD. Di bidang morfologi, ditemukan bentuk-bentuk kata yang kurang tepat. Di bidang sintaksis, ditemukan berbagai pengaruh dari BA ke BI baik yang negatif maupun positif. Di bidang semantic, ditemukan berbagai istilah bahasa Indonesia yang telah lazim dan dipergunakan secara umum yang berasal dari terjemahan harfiah dan istilah yang terdapat dalam al-Qur'an.

\section{Simpulan}

Hasil analisis dan pembahasan di atas dapat disimpulkan hal-hal sebagai berikut:

1. Berdasarkan analisis fungsi, sebuah ayat al-Qur'an (BA) yang diterjemahkan secara harfiah belum tentu meng- hasilkan terjemahan yang mempunyai pola sintaksis yang sama dengan bahasa sumbernya (BA). Dengan kata lain, pola kalimat BI sering berbeda dengan pola kalimat BA meskipun kalimat BI tersebut merupakan terjemahan harfiah dari kalimat BA. Hal itu terjadi disebabkan oleh cara kerja yang berbeda antara yang dilakukan oleh tatabahasawan bahasa Arab dengan cara yang ditempuh oleh tata bahasawan bahasa Indonesia dalam melakukan analisis fungsinya.

2. Analisis komparatif terhadap BA dan BI, yang sering dilakukan berdasarkan analisis fungsi, tidak dapat dijadikan patokan dalam menentukan apakah suatu terjemahan (BI) mengikuti pola struktur ayatnya (BA) atau tidak mengikutinya.

3. Untuk menelusuri apakah sebuah terjemahan mengikuti pola struktur BA atau tidak, harus dilakukan penelaahan terhadap susunan kata (pola urutan) yang menjadi unsur BA dan BI. []

\section{Daftar Rujukan}

Catford, J.C., A Linguistic Theory of Translation, Oxford: Oxford University Press, 1965.

Enani, Muhammad, Fann al-Tarjamah, Beirut: Maktabah Lubnan Nasyirun, 2004.

Kridalaksana, Harimurti, Fungsi Bahasa dan Sikap Bahasa, Ende: Nusa Indah, 1999.

Majid, A.M., Sejarah Kebudayaan Islam, terjemah Ahmad Rafi' Usmani, Bandung: Pustaka, 1997.

Mansyur, Muhammad dan Kustiwan, Dalîl al-Kâtib wal-Mutarjim, Jakarta: Moyo Segoro Agung, 2002. Moeliono, A.M. (ed), Tata Bahasa Baku Bahasa Indonesia, Jakarta: Balai Pustaka, 1989.

Nida, Eugene A. and Taber, Charles R., The Theory and Practice of Translation, Leiden: E.J. Brill, 1982. al-Qhaththan, Mannâ' Khalîl, Mabâhits fî 'Ulûm al-Qur'ân, Kairo: Maktabah Wahbah, 2000.

Rochayah Machali, Redefining Textual Equivalence in Translation, Jakarta: Pusat Penerjemahan Fakultas Sastra UI, 1998.

Suryawinata, Zuchridin dan Hariyanto, Sugeng, Translation: Bahasan Teori dan Penuntun Praktis Menerjemahkan, Yogyakarta: Kanisius, 2003.

Syihabuddin, Penerjemahan Arab Indonesia: Teori dan Praktek, Bandung: Humaniora, 2005.

Tim Penyusun, al-Qur'an al-Karim dan Terjemahnya, Jakarta: Departemen Agama, 1997.

al-Zarqânî, Muhammad 'Abd al-'Azhim, Manâhil al-'Irfân fî 'Ulûm al-Qur'ân, Mesir: Mustafa al-Babi al-Halabi wa Auladuh, $1411 \mathrm{H}$ 